\title{
Development characteristics of the fault system and its control on basin structure, Bodong Sag, East China
}

\author{
Wu Zhiping ${ }^{*}$, Cheng Yanjun¹, Yan Shiyong ${ }^{1}$, Su Wen², Wang Xin ${ }^{2}$, Xu \\ Changgui ${ }^{2}$ and Zhou Xinhuai ${ }^{2}$
}

${ }^{1}$ China University of Petroleum, Qingdao, Shandong 266580, China
${ }^{2}$ Tianjin Technical Department, CNOOC, Tianjin 300452, China

(C) China University of Petroleum (Beijing) and Springer-Verlag Berlin Heidelberg 2013

\begin{abstract}
The Bodong Sag, located in the Bohai Sea, offshore China, is one of the most petroliferous basins in China. Based on three dimensional seismic reflection data and time slice data, we analyze the fault system of the Bodong area in detail, establish the fault structure pattern of different types and summarize the distribution of the fault system. It is concluded that the development characteristics of the Cenozoic fault system are in accordance with the dextral stress field of the Tanlu Fault, which displayed a brush structure with NNE strike-slip faults as its principal faults, NE-trending extensional faults as secondary faults and EW-trending faults as minor faults. Faults can be divided into (1) strike-slip type, (2) extensional type, (3) strike-slip extensional type and (4) extensional strike-slip type. The spatial structures of different faults have obvious differences because of the fault properties and activity intensity. The fault system at different stages shows tremendous differences because of the transition of the Tanlu Fault from sinistral strike-slip to dextral strike-slip, the transition between extension and strike-slip, and the transition from mantle upwelling to thermal subsidence. According to the controlling effect of faults on basin structure, the Cenozoic basin experienced four evolutionary stages, (a) transition stage from sinistral strike-slip to dextral strike-slip, (b) strike-slip extensional faulted stage, (c) extensional strike-slip faulted stage and (d) strike-slip depression stage. The identification of temporal and spatial differences of faults could be used as a significant guideline for oil and gas exploration in the Bodong area.
\end{abstract}

Key words: Fault system, basin structure, Bodong area

\section{Introduction}

The Bodong area is situated in the eastern Bohai area, East China and is surrounded by the Jiaoliao Uplift in the east, Bozhong Sag in the west, and the Liaodong Bay Sag in the north (Fig. 1) (Xiu et al, 2013; Qi and Yang, 2010; Jiang et al, 2011). It is one of the most petroliferous basins of Bohai area, and is about $6,000 \mathrm{~km}^{2}$ in area. The study area contains four secondary structure units: the Bodong Sag, Miaoxi Sag, Bodong Low Uplift, and the Miaoxi Uplift. The Bodong area is considered as an important target area of the Bohai Bay Basin with great exploration potential and several mid-large scale oil and gas fields have already been found (Gong et al, 2007; Zhu et al, 2009; Zuo et al, 2011).

Faulting is the main deformation mode of the sag and the main controlling effect of the basin structure ( $\mathrm{Li}$ et al, 2012). Under the joint action of the Tanlu Fault's strike slip, subduction of the Pacific Plate and mantle upwelling, the fault system displays a superimposed effect of the extensional

*Corresponding author. email: wuzp@upc.edu.cn

Received June 20, 2013 fault system (Paleogene) and the strike-slip fault system (late Paleogene and Neogene) (Tong et al, 2008; Li et al, 2011; Yu et al, 2009; Chen et al, 2012; Wan et al, 2009; Zhao and Zheng, 2005), which results in the diversity of the fault trends, properties and spatial structure.

Based on abundant three dimensional seismic data, we analyzed the 3D characteristics of the fault system by combining analysis of profiles and time slices, which broke through the former researchers' limitation of 2D analysis of the fault, and established the 3D structure pattern of faults. Furthermore, we analyzed the control of fault systems on the basin structure, aiming at guiding oil and gas exploration.

\section{Basin-controlling fault system of the Bodong Sag}

\subsection{Feature of the main faults}

The NNE, NW, NE, NEE and WNW trending faults are well developed in the Bodong area. This paper systematically describes the main basin-controlling faults by analysis of the characteristics of seismic sections and time slices (Fig. 2, Fig. $3)$. 


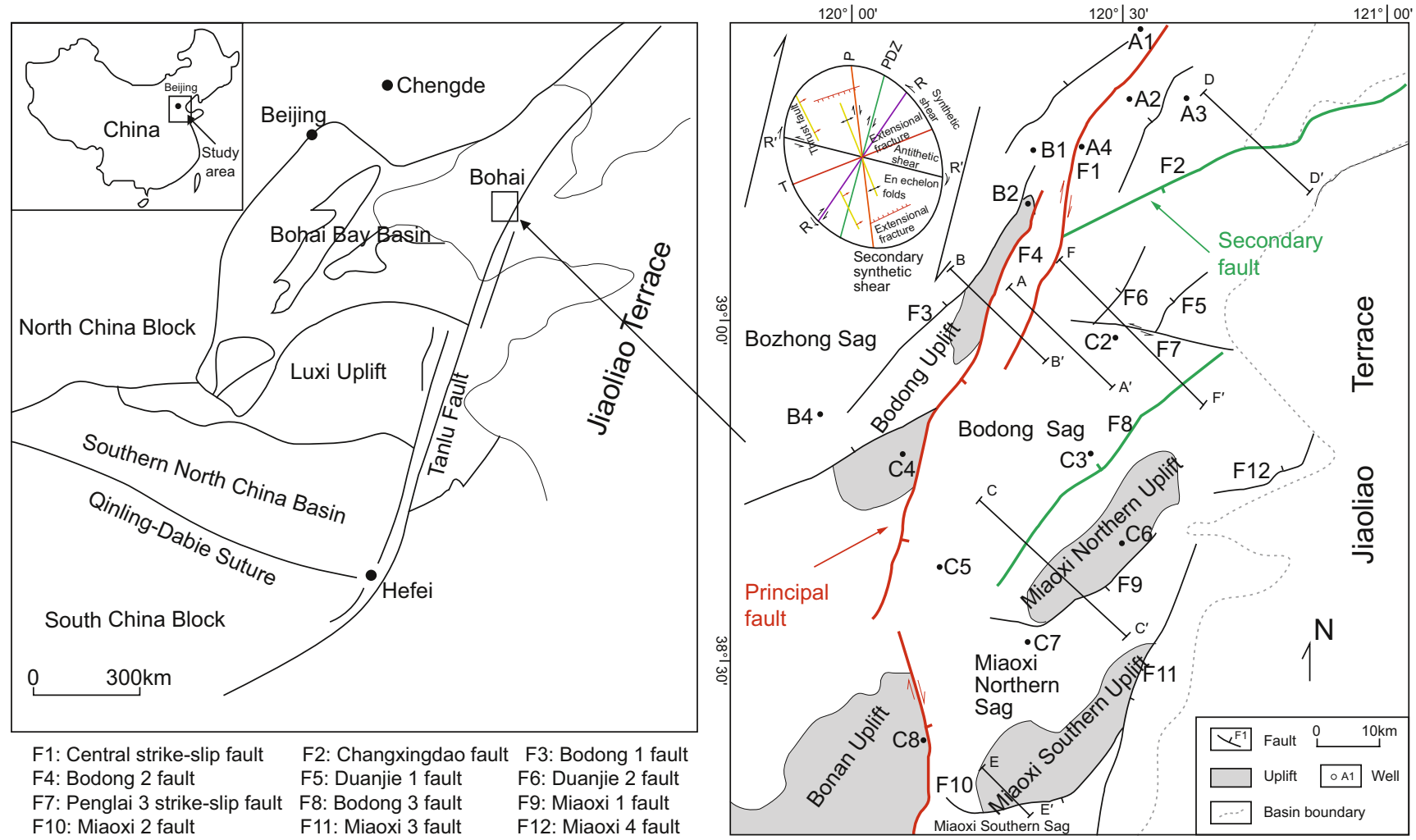

Fig. 1 The partition of the structure element and the distribution of the main faults. The brush structure developed in the Bodong Sag with NNE strike-slip faults as its principal faults (red ones), the NE-trending extensional faults as secondary faults (green ones) and the EW-trending faults as minor faults
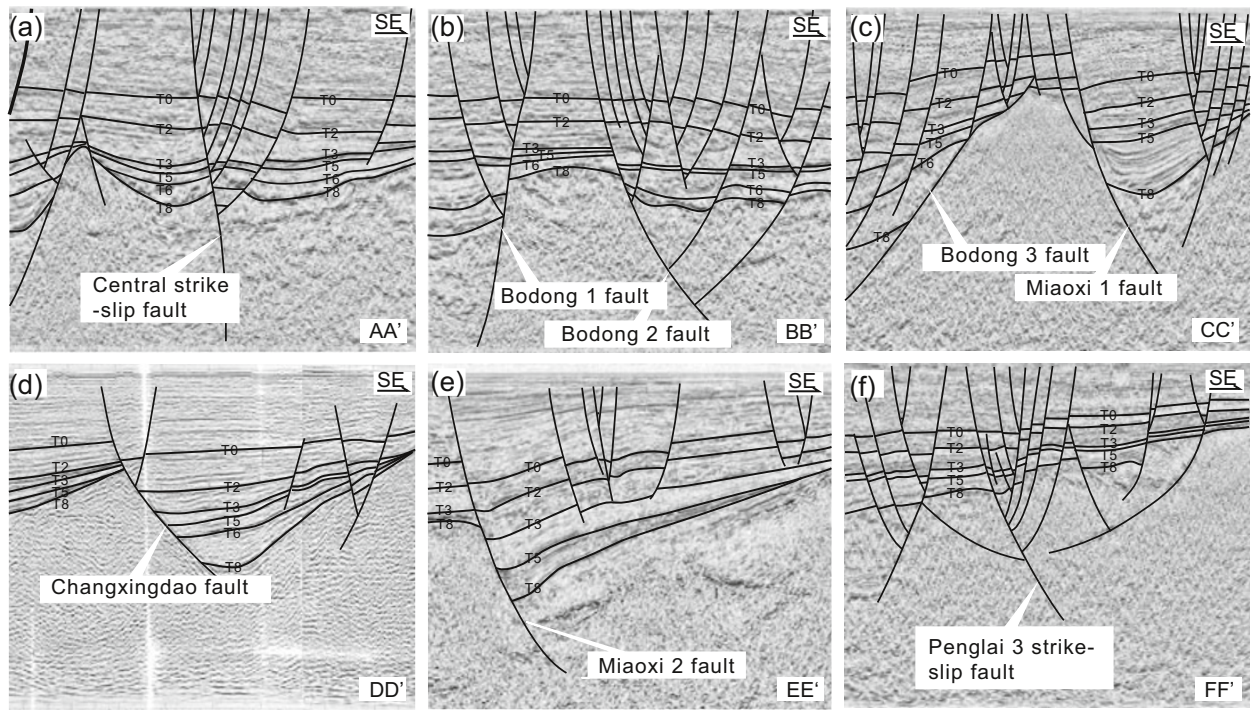

Fig. 2 Seismic section showing the main faults in the Bodong area

Central strike-slip fault: As the largest-scale fault in the area, the fault is part of the Tanlu strike-slip fault zone. It is developed in the middle part of the Bodong Sag with an NNE-SSW trending, almost vertical fault plane indicating remarkable strike-slip features. In section, the fault shows negative flower structure and multi-step " $Y$ " shape structure (Fig. 2(a)). In plan view, the fault usually appears as one fault at depth, while as en-echelon arrangement of nearly EW trending secondary faults closer to the surface (Fig. 3(a)).

Bodong 1 and Bodong 2 fault: The faults are the boundary faults of the Bodong Low Uplift in the west and east sides respectively, parallel to the central strike-slip fault, NNESSW trending and extending about $30-40 \mathrm{~km}$. The Bodong 1 fault is a high-angle normal fault with WNW dip, and is composed of a "Y" shape fault with secondary faults closer to the surface in section (Fig. 2(b)). In plan view, the west wall of the fault is composed of a series of EW secondary faults with feather-like arrangement closer to the surface, but it appears as a linear fault at depth (Fig. 3(b)). The Bodong 2 fault is a listric normal fault or multi-step "Y" shape fault with ESE dip, and the dip angle decreases from north to south (Fig. 2(b)). The fault appears as an NS linear fault at 


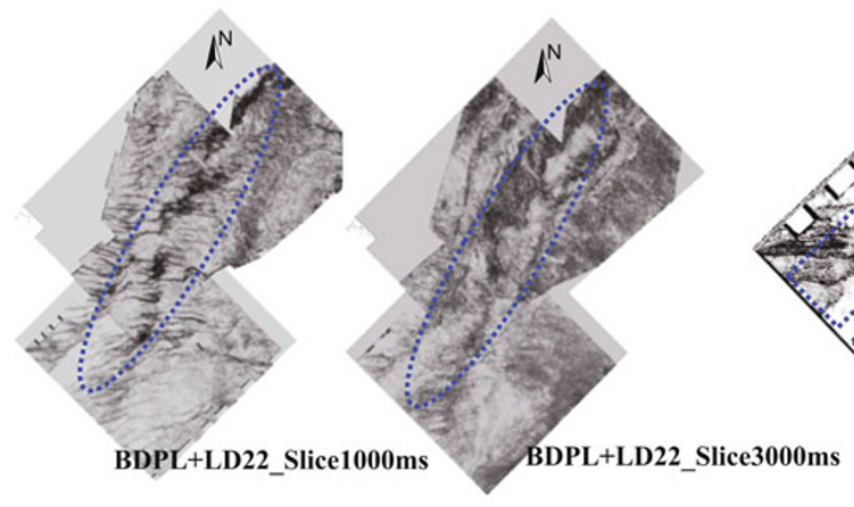

(a) Central strike-slip fault

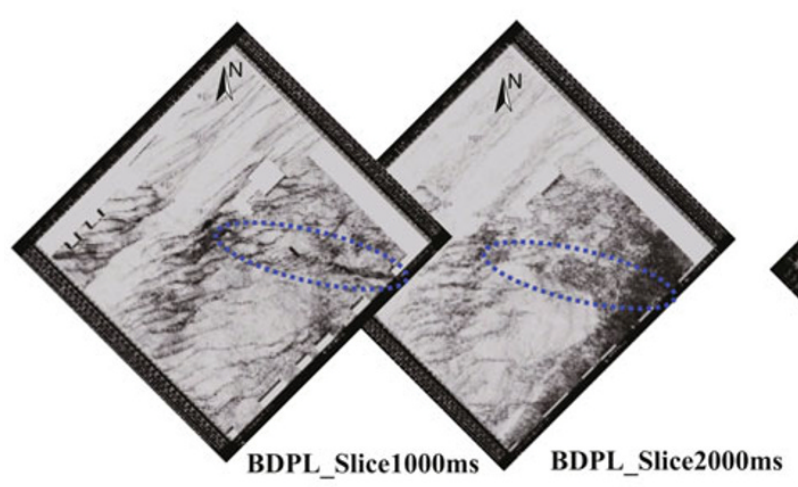

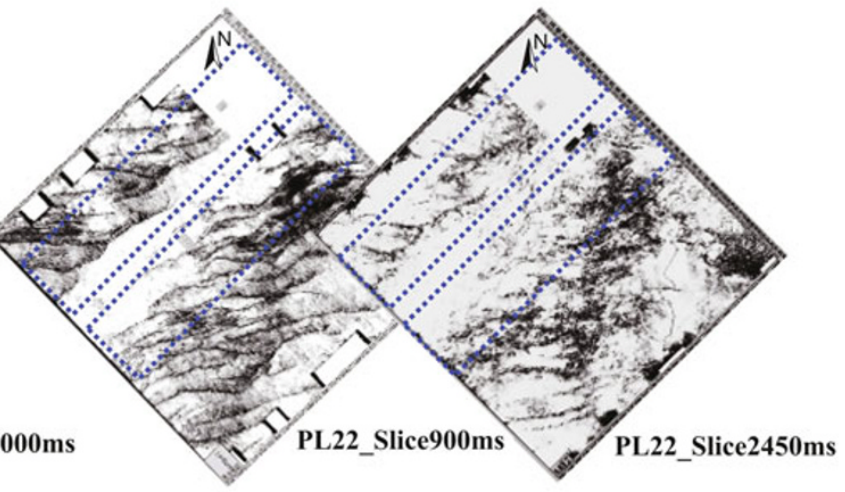

(b) Bodong 1 fault (left), Bodong 2 fault (right)

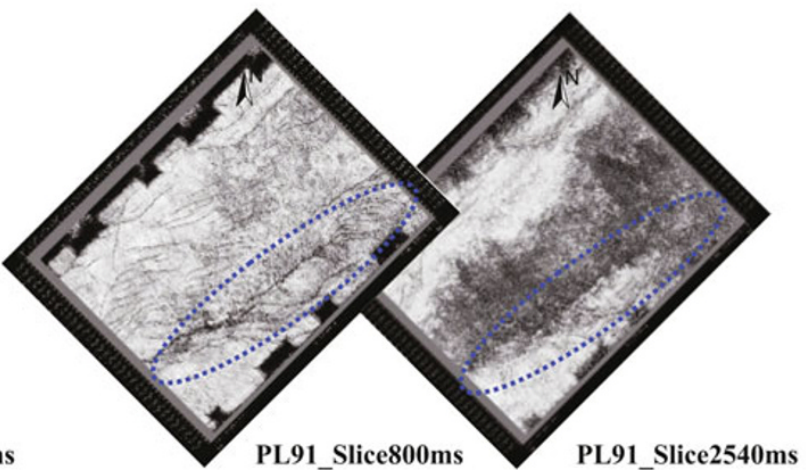

Fig. 3 Plane characteristics of the main faults in the Bodong area on time slices of various depths

depth, and a series of NE secondary faults develop including secondary faults with feather-like arrangement of nearly EW trend in the east wall closer to the surface.

Bodong 3 fault: The fault is the boundary fault between the Bodong Sag and the Miaoxi Northern Uplift with an NESW trend and NW dip, and extends about $30 \mathrm{~km}$. In section, it displays as a listric fault, or a "Y" shape fault with secondary faults in its hanging wall (Fig. 2(c)). In plan view, it is a linear fault at depth, and becomes a series of nearly EW trending en-echelon faults closer to the surface. It intersects with the Penglai 3 strike-slip fault in the northeast and with the central strike-slip fault in the southwest.

Changxingdao fault: The fault is the north boundary fault of the Bodong Sag NE trending with an SE dip, and extends $32.7 \mathrm{~km}$. In section, it displays as a listric fault or forms a "Y" shape fault with secondary faults in its hanging wall (Fig. 2(d)).

Miaoxi 1 fault: The fault, which controls the formation and evolution of the Miaoxi Northern Sag, is the south boundary fault of the Miaoxi Northern Uplift NE trending with an SE dip and extends about $45.2 \mathrm{~km}$. In section (Fig. $2(c)$ ), it is a listric normal fault in the northeastern part of the fault, and displays a flower structure or multi-step "Y" shape structure in the southwestern part near the central strike-slip fault. In plan view, it is a single linear fault at depth, and then presents as a series of secondary faults closer to the surface in the southwest of the fault.

Miaoxi 2 fault: The fault which controls the formation and evolution of the Miaoxi Southern Sag, is the southern boundary fault of the Miaoxi Southern Uplift, NE trending with an SE dip and extends $38.7 \mathrm{~km}$. In section, it displays as a normal listric fault with few secondary faults (Fig. 2(e), Fig. 3(d)).

Penglai 3 strike-slip fault: The fault is located in the eastern gentle slope belt of the Bodong Sag WNW-ESE trending with an SW dip and a high dip angle which is almost vertical, and extends about $16-20 \mathrm{~km}$. In section, it displays a flower structure or multi-step " $Y$ " shape structure with secondary faults of the upper formation (Fig. 2(f)). In plan view, it displays a linear fault at depth, and a feather-like fault structure closer to the surface which is composed of an EWstriking main fault and a series of NS secondary faults (Fig. $3(\mathrm{~d}))$.

There are several relatively large-scale faults beside the above mentioned faults, such as the Duanjie 1, Duanjie 2 and Miaoxi 3 faults. The former two, located in the eastern gentle slope belt of the Bodong Sag, are listric normal faults with high dip angle, NNE trending and WNW dipping. They present "Y" shape structure with secondary faults closer to the surface and intersect with the Penglai 3 strike-slip fault in the southwest. The Miaoxi 3 fault, which is a listric normal fault with NNE trending and ESE dip, is in the southeast of the Miaoxi Southern Uplift, and extends about $30 \mathrm{~km}$. In plan view, the fault presents a linear fault at depth, and enechelon arrangement of secondary faults closer to the surface. This fault controls the formation and evolution of the Miaoxi Eastern Sag.

Moreover, the en-echelon EW secondary faults usually 
develop along the ENE-trending principal strike-slip fault closer to the surface.

\subsection{Types of the faults}

The analysis of fault development characteristics indicates that the faults are not a single plane. In fact, they always form a fault zone accompanied by several secondary faults. The spatial structure of the faults with different properties presents differences, and the spatial structure of one fault also differs at different depths. Therefore, faults in the study area can be divided into four types including (1) strike-slip fault, (2) extensional strike-slip fault, (3) strike-slip extensional fault, and (4) extensional fault. The strike-slip faults can be further divided into three types by the intensity of the strike-slip movement (Fig. 4).

\subsubsection{Strike-slip fault}

The strike-slip fault is also named "translational fault" and is controlled by shear stress. The two walls of the fault move relative to each other along the trend of the fault, and the vertical displacement is minor. The development of faults in the study area is controlled by the strike-slip effect of the Tanlu Fault, so strike-slip faults are the most obvious tectonic deformation in this area. The structure patterns of faults experiencing different strike-slip intensity are distinctive, dominated by the stress and the displacement of the strike-slip fault.

Strong strike-slip fault: The principal strike-slip zone is well developed with feather-like secondary faults on the two walls. The major fault is nearly vertical and composes a flower structure or multi-step "Y" shape structure with secondary faults in the upper formations in section, for example, the central strike-slip fault (Fig. 4(a)).

Moderate intensity strike-slip fault: This kind of fault has a main but discontinuous strike-slip fault plane with featherlike secondary faults in the two walls. In section, it displays a flower structure or multi-step "Y" shape structure, for example, the Penglai 3 strike-slip fault (Fig. 4(b)).

Weak strike-slip fault: This kind of fault does not have a major strike-slip fault plane in section. They are made up of a series of secondary en-echelon faults, which just cut a few shallow formations. Lots of secondary faults in the shallow formations always have these features in the study area (Fig. 4(c)).

\subsubsection{Extensional strike-slip fault}

This kind of fault is dominated by the strike-slip, and develops coevally with the extension. It is composed of a series of en-echelon secondary faults with a nearly EW trend, which are connected along the main strike-slip direction laterally, and form one main fault plane with poor connectivity. They display a "Y" shape structure and column structure in section, such as the Bodong 1 and Bodong 2 faults (Fig. 4(d)).

\subsubsection{Strike-slip extensional fault}

This kind of fault is dominated by extensional stress and develops under the influence of weak shear stress. The major fault is a high dip angle listric normal fault and forms a "Y" shape in section. The feather-like secondary faults of the foot wall intersect with the major fault in plan view. The NNE boundary faults between the sag and the uplift, such as the Miaoxi 1 and Bodong 3 faults, can be attributed to this type (Fig. 4(e)).

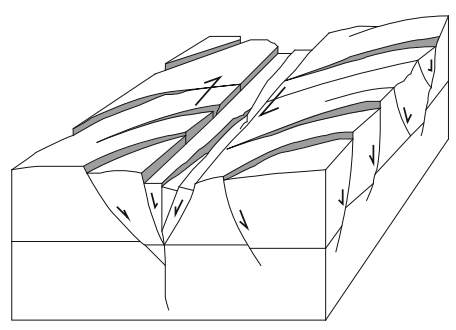

(a) Strong strike-slip fault pattern

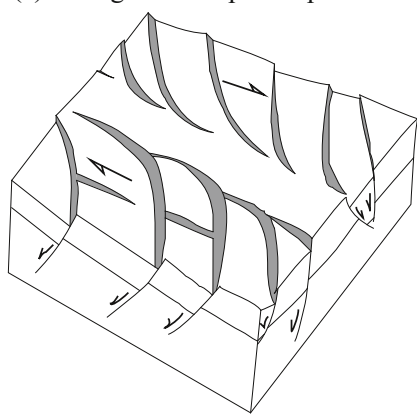

(d) Extensional strike-slip fault

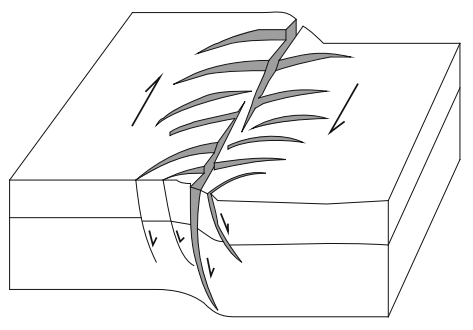

(b) Moderate intensity strike-slip fault

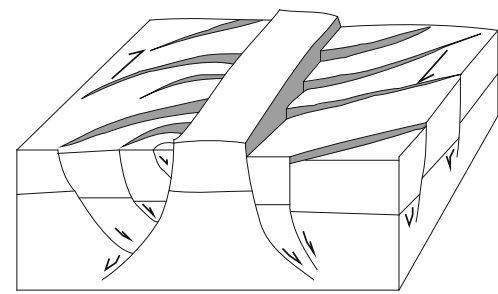

(e) Strike-slip extensional fault

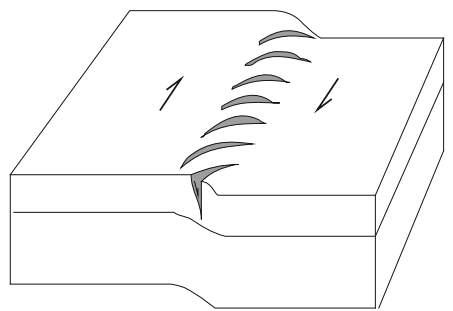

(c) Weak strike-slip fault

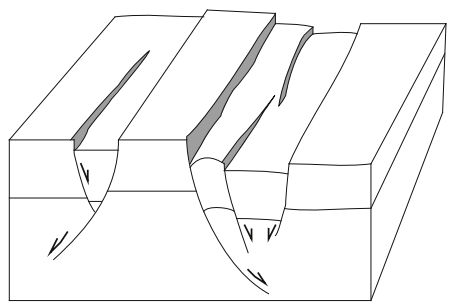

(f) Extensional fault

Fig. 4 The type and pattern of the main faults

\subsubsection{Extensional fault}

The major fault is a listric normal fault with parallel secondary faults in the footwall, which form the "Y" or reversed "Y" shape structure pattern in section, such as Miaoxi 2 fault and Changxingdao fault (Fig. 4(f)).

\subsection{Distribution characteristics of the faults}

Based on the analysis of the structure pattern and the distribution regulation of main faults, we infer that the fault system of the Bodong Sag is in accordance with the dextral stress-field of the Tanlu Fault, as the stress ellipsoid of Fig. 1 
shows. The NNE central strike-slip fault, Bodong 1 fault and Bodong 2 fault can be attributed to the strike-slip fault pattern or the extensional strike-slip fault pattern, which correspond to the principal displacement zone (PDZ) or the secondary synthetic faults (Principal (P) shears, Riedel (R) shears). The NE Changxingdao fault, Miaoxi 1 fault, Miaoxi 2 fault and Bodong 3 fault can be described as extensional faults, which developed during the formation of the NNE large-scale dextral strike-slip faults. The NW Penglai 3 strike-slip fault, an antithetic strike-slip fault intersecting with the PDZ at a high angle, corresponds to $\mathrm{R}$ shears.

As for the vertical characteristics of the faults, first, the lower strata (from the Kongdian Formation to the $3^{\text {rd }}$ member of the Shahejie Formation) are cut by the NNE strike-slip fault and extensional strike-slip fault. The faults cutting the Cenozoic basin basement have a consecutive fault plane and few secondary faults develop. Second, the NNE strike-slip fault and extensional strike-slip fault become discontinuous in the middle strata (from the $2^{\text {nd }}$ member of the Shahejie Formation to the Dongying Formation), and are composed of a series of NE en-echelon secondary faults which are distributed along the NNE direction. The fault plane of the NE extensional fault is successive and stable. The main faults in the upper strata (from the Guantao Formation to present) turned into a series of en-echelon secondary faults, and did not have a principal fault plane. Thus, the vertical structure pattern of the faults in different structural belts is different (Fig. 5).

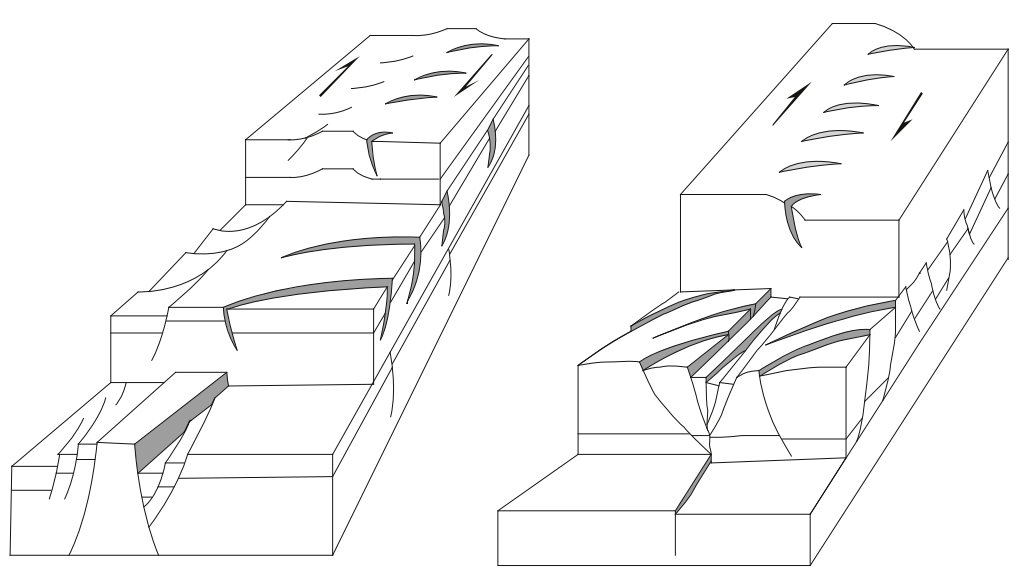

(a) The controlling fault of the Bodong lower uplift

(b) The central strike-slip fault

Fig. 5 The vertical difference of the main fault in a typical area of the Bodong Sag

The diversity of the fault system is caused by the differences of the stress field and the strike-slip displacement in different periods, and it is also related to the properties of the strata: 1) the strike-slip faults are accompanied by syndepositional processes; 2) different strata have different strike-slip displacement because of tectonic movement during deposition. The shallow layers have small strike-slip displacement and the plasticity is better, while deep layers have large displacement. These may be the most important reasons for the vertical difference of structure patterns of the fault zone.

\section{Basin evolution of the Bodong Sag}

According to the previous research and regional stress background, the main dynamic sources of the tectonic deformation of eastern China are the horizontal extension generated from mantle upwelling, and the NE-SW lateral compression which comes mainly from the collision between the Pacific Plate and Eurasian Plate (Cheng et al, 2013; Zou et al, 2010; Yang et al, 2013; Ling, 2009; Zhou et al, 2012; Huang et al, 2009; Chen et al, 2010; Qi et al, 2010; 2008; Gong et al, 2011; Konyukhov and Chen, 2007). As a result, the large-scale NW faults (Zhangjiakou-Penglai fault, Qinhuangdao-Lüshun fault) and NE faults (Tanlu Fault,
Lanliao Fault) were developed, which formed the conjugate shear fracture system of the Bohai Bay Basin (Yu et al, 2008; Qi et al, 2008; Zhang et al, 2009; Mercier et al, 2012). As for the Bodong Sag, the basin is controlled by the fault system which displays a brush structure (Fig. 1) with the NNE strikeslip as its principal fault, the NE-trending extensional faults as secondary faults and the EW-trending faults as minor faults.

The difference of the fault system at each stage is caused by the transformation of the Tanlu Fault zone from sinistral strike-slip to dextral strike-slip, the transformation of the intensity of extension and strike-slipping, and the transformation from horizontal extension caused by the mantle upwelling to thermal subsidence. Based on the fault activity and numerical simulation of the regional stress field, we propose that the basin experienced four important evolution stages in Cenozoic (Fig. 6).

1) Ek-Es $s_{4}$ stage (65-53 Ma): sinistral strike-slip to dextral strike-slip transition stage

During the sedimentation of the Kongdian Formation and the $4^{\text {th }}$ member of the Shahejie Formation, the study area experienced the transition from the Yanshan Movement to the Himalayan Movement. During the Yanshan Movement period, the subduction direction of the Pacific Plate under the Eurasian Plate was NNW. The Tanlu Fault and Lanliao Fault 


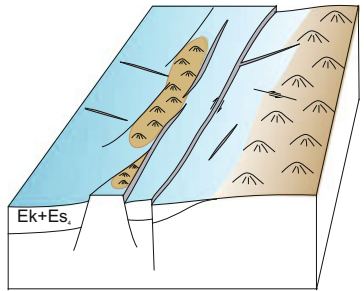

(a) ${\mathrm{Ek}-\mathrm{Es}_{4}}_{4}(65-42 \mathrm{Ma})$

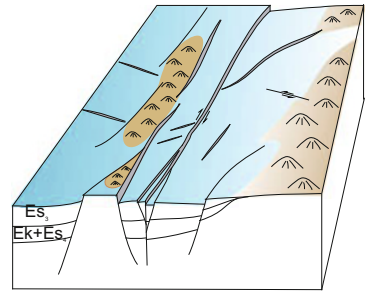

(b) $\mathrm{Es}_{3}(42-38 \mathrm{Ma})$

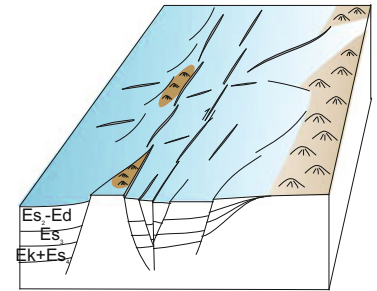

(c) $\mathrm{Es}_{2}-\mathrm{Ed}(38-24.6 \mathrm{Ma})$

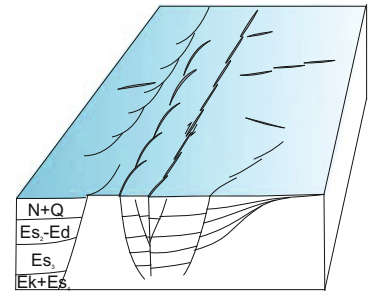

(d) N+Q (24.6 Ma-present)

Fig. 6 The evolution pattern of the basin structure of the Bodong area

experienced sinistral strike-slip movement. So the Bohai Bay Basin was controlled by NNE strike-slip faults and NW extensional faults. The NW fault system formed under the superimposed influence of the NE-SW extensional stress derived from the NNE strike-slipping of Tanlu and CangdongLanliao strike-slip faults and the horizontal extension stress generated from mantle upwelling (Grimmer et al, 2002; Li et al, 2010a). From the late Yanshan Movement period to the early Himalayan Movement period, North China experienced dextral strike-slip because of the change of the Pacific Plate subduction direction from NNW to WNW (Hou et al, 2001; Zhou and Zhou, 2006) and the northward subduction and collision of the Indian Plate towards the Eurasian Plate $(\mathrm{Xu}$ and Zhang, 1999) which resulted that the movement of the Tanlu and Cangdong-Lanliao fault changed from sinistral strike-slip to dextral strike-slip movement.

In the study area, the Tanlu Fault zone experienced the transformation from sinistral strike-slip to dextral strike-slip, and the stress field was a superimposed effect of the weak strike-slip and strong extension. The NNE faults had weak extension and vertical activity with an activity rate of less than $20 \mathrm{~m} / \mathrm{Ma}$. Among the NE extensional faults' activity, only the Changxingdao fault had a weak activity, however, the Bodong 3 fault, Miaoxi 1 fault and Miaoxi 2 fault were nearly inactive. Therefore the sedimentation was mainly controlled by the NNE strike-slip faults and the distribution of the depocenter was in the NNE direction (Fig. 6(a)).

2) Es $_{3}$ stage (42-38 Ma): superimposed effect of strong extension and dextral strike-slip

At this stage, the transition movement of the Tanlu Fault had completed. The Tanlu Fault underwent strong dextral strike-slipping, at the same time, the horizontal extension generated from mantle upwelling became stronger. Under this geological background, the framework of the fault system that "the NNE strike-slip fault as its principal fault and the NE extensional faults as secondary ones" had formed preliminarily, and the vertical activity of the central strikeslip fault, Bodong 1 fault, Bodong 2 fault had increased. Meanwhile, the vertical activity of the NE extensional fault, such as Miaoxi 1 fault, Bodong 3 fault and Changxingdao fault gradually increased (Fig. 6(b)).

3) Es -Ed stage (38-24.6 Ma): superimposed effect of strong dextral strike-slip and extension, uplift and erosion at late Ed

At this stage, the overall stress field was similar to the depositional stage of the $3^{\text {rd }}$ member of the Shahejie Formation, while the ratio between the shear stress and the horizontal extensional stress had begun to change. With the weak extensional stress and the strong shear stress, the superimposed effect of strong strike-slip and weak extension formed. The fault system at this stage resembled the $\mathrm{Es}_{3}$ stage in the framework but presented different activity. The NNE Bodong 1 fault, Bodong 2 fault, and NE Miaoxi 1 fault had intense vertical movement, while the vertical activity of the central strike-slip fault was relatively weak. At the same time, the NNW antithetic strike-slip faults (such as the Penglai 3 strike-slip fault) started to develop. However, the vertical activity was weak. The main strike-slip faults displayed as a series of en-echelon secondary faults (Fig. 6(c)).

At the end of the Paleogene, the collision between the Indian and Eurasian plates resulted in the eastward escape of the North China Plate (He et al, 1998). Furthermore, the lateral subduction of the western Pacific Plate in the Paleogene led to the back-arc spreading of the Japan Sea Basin (Zhu et al, 2004), as a result, a westward lateral compression force formed. The combined action of these made the eastern part of North China lie in the EW-trending compression force field. Meanwhile, the movement style of the Tanlu Fault changed gradually to a thrust fault with dextral strike-slip. Therefore, under the joint action of the basin uplift resulting from the increasing thickness of the deep crust and the compression stress field closer to the surface derived from the plate movement, the uplift and erosion of the Bohai Bay Basin occurred at the end of the Paleogene.

\section{4) $N+Q$ stage (24.6 Ma-present): superimposed effect of depression and strike-slip}

In the Neogene, the strong mantle upwelling and lithosphere thinning resulted in continuous extension. The increase of sedimentary load, the rise of the temperature of the lower crust and continuous thermal anomaly of the asthenosphere led to a reduction of elastic stiffness and a decrease of the effective elastic thickness of lithosphere. The lithosphere began to shift from brittle deformation to plastic deformation, and the loading effect of the sediment started to convert from regional flexure isostatic compensation to local equilibrium, which resulted in a redistribution of terrain height differences due to the local equilibrium mechanism (Li et al, 2010b). These, together with the succeeding thermal subsidence, resulted in regional depression. Therefore, the strike-slip function became the dominant factor in the study area, and the whole fault system with weak vertical activity displayed as an EW en-echelon arrangement distributed along the NNE direction. Compared to the former stage, the vertical activity rate of faulting decreased by one order of magnitude 
(Fig. 6(d)).

In conclusion, the evolution of the study area was controlled by superimposed regional stress, including the strike-slipping of the Tanlu Fault and the extension of mantle upwelling. It has experienced four evolution stages: transition stage from sinistral strike-slip to dextral strike-slip, strikeslip extensional faulted stage, extensional strike-slip faulted stage, and strike-slip depression stage. The superimposed relationship and differences of the basin structure are controlled by the fault system at different stages, which dominate the material filling and the material foundation of hydrocarbon accumulations.

\section{Conclusions}

1) The fault system of the Bodong Sag can be described as a brush structure with an NNE strike-slip fault as its principal fault, NE-trending extensional faults as secondary faults and EW-trending faults as minor faults. It controlled the structure pattern of the basin.

2) The feature of the Cenozoic Bodong fault system corresponds to the dextral stress field of the Tanlu Fault. The fault system can be divided into four basic types, (1) strike-slip fault, (2) extensional strike-slip fault, (3) strikeslip extensional fault and (4) extensional fault. Under the influence of fault properties and activity intensity, different faults have different fault structure patterns.

3) There are obvious differences among the Bodong fault systems at different stages, which are influenced by the transition of the Tanlu Fault from sinistral strike-slip to dextral strike-slip, the transition of the intensity of extension and strike-slip, and the transition from horizontal extension generated from mantle upwelling to thermal subsidence. As a result, the development of Cenozoic basin can be divided into four evolutional stages: (a) transition stage from sinistral strike-slip to dextral strike-slip, (b) strike-slip extensional faulted stage, (c) extensional strike-slip faulted stage and (d) strike-slip depression stage.

4) Not only have the faults controlled the basin structure, but also they dominate the reservoirs. Therefore, the study of controlling function of the faults on hydrocarbon accumulation, starting with the structural differences of different types of faults and the structural differences of one fault in different strata, will become an important aspect of petroleum geology research in the study area.

\section{References}

Chen K, Qi J F, Liu Z, et al. Characteristics of Cenozoic fault systems and dominating action on hydrocarbon accumulation in eastern Bohai Sea area. Geological Science and Technology Information. 2012. 31(1): 63-71 (in Chinese)

Chen S P, Zhou X H, Tang L J, et al. Wrench-related folding: A case study of Bohai Sea Basin, China. Marine and Petroleum Geology. 2010. 27(1): 179-190

Cheng C, Chen L, Yao H J, et al. Distinct variations of crustal shear wave velocity structure and radial anisotropy beneath the North China Craton and tectonic implications. Gondwana Research. 2013. 23(1): $25-38$

Gong Y L, Zhang H and Ye T F. Heat flow density in Bohai Bay Basin: Data set compilation and interpretation. Procedia Earth and
Planetary Science. 2011. 2: 212-216

Gong Z S, Cai D S and Zhang G C. Dominating action of Tanlu Fault on hydrocarbon accumulation in eastern Bohai Sea area. Acta Petrolei Sinica. 2007. 28(4): 1-10 (in Chinese)

Grimmer J C, Jonckheere R, Enkelmann E, et al. Cretaceous Cenozoic history of the southern Tan-Lu fault zone: Apatite fission-track and structural constraints from the Dabie Shan (eastern China). Tectonophysics. 2002. 359(3): 225-253

He H Q, Wang Z Y and Han P L. Tectonic control on the formation and distribution of oil-gas pools in the Bohai Bay Basin of North China. Acta Geologica Sinica. 1998. 72(4): 313-322 (in Chinese)

Hou G T, Qian X L and Cai D S. The tectonic evolution of Bohai Basin in Mesozoic and Cenozoic time. Acta Scicentiarum Naturalum Universitis Pekinesis. 2001. 37(6): 845-851 (in Chinese)

Huang Z X, Li H Y, Zheng Y J, et al. The lithosphere of North China Craton from surface wave tomography. Earth and Planetary Science Letters. 2009. 288(1-2): 164-173

Jiang Z X, Liu H, Zhang S W, et al. Sedimentary characteristics of largescale lacustrine beach-bars and their formation in the Eocene Boxing Sag of Bohai Bay Basin, East China. Sedimentology. 2011. 58(5): 1087-1112

Konyukhov A I and Chen X J. Lithology and formation conditions of Paleogene rocks in the Dongying Depression (Bohai Bay Basin, China). Lithology and Mineral Resources. 2007. 42(6): 551-557

Li S Z, Zhao G C, Dai L M, et al. Cenozoic faulting of the Bohai Bay Basin and its bearing on the destruction of the eastern North China Craton. Journal of Asian Earth Sciences. 2012. 47: 80-93

Li W, Wu Z P and Zhao W D. Structural characteristics and basin transformation in the Bohai Bay Basin in the Yanshan Era. Progress in Geophysics. 2010a. 25(6): 2068-2077 (in Chinese)

Li X S, Zhao Y X, Liu B H, et al. Structural deformation and fault activity of the Tanlu fault zone in the Bohai Sea since the Late Pleistocene. Chinese Science Bulletin. 2010b. 55(18): 1908-1916

Li Y Y, Yang Y S and Kusky T M. Lithospheric structure in the North China craton constrained from gravity field model. Journal of Earth Science. 2011. 22(2): 260-272

Ling C. Lithospheric structure variations between the eastern and central North China craton from S- and P-receiver function migration. Physics of the Earth and Planetary Interiors. 2009. 173(3-4): 216-227

Mercier J L, Vergely P, Zhang Y Q, et al. Structural records of the Late Cretaceous-Cenozoic extension in eastern China and the kinematics of the southern Tanlu and Qinling fault zone. Tectonophysics. 2012. 582: $50-75$

Qi J F and Yang Q. Cenozoic structural deformation and dynamic processes of the Bohai Bay Basin province, China. Marine and Petroleum Geology. 2010. 27(4): 757-771

Qi J F, Deng R J, Zhou X H, et al. The structure of the Tanlu Fault zone in Cenozoic basin, Bohai Bay. Science in China. 2008. 38(S1): 19-29 (in Chinese)

Qi J F, Zhou X H and Wang Q S. Structural model and Cenozoic kinematics of Tanlu deep fracture zone in Bohai Sea area. Geology in China. 2010. 37(5): 1231-1242 (in Chinese)

Qi J F, Zhou X H, Deng R J, et al. Structural characteristics of the Tanlu Fault zone in Cenozoic basins offshore the Bohai Sea. Science in China Series D: Earth Sciences. 2008. 51(2): 20-31

Tong H M, Yu F S and Geng C B. Characteristics and evolution of strike-slip tectonics of the Liaohe Western Sag, Bohai Bay Basin. Petroleum Science. 2008. 5(3): 223-229

Wan G M, Tang L J, Zhou X H, et al. Tectonic characteristics of the Tanlu Fault zone in Bodong area of Bohai Sea. Acta Petrolei Sinica. 2009. 30(3): 342-346 (in Chinese)

Xiu Z X, Liu B H, Xie Q H, et al. Assessment of structural stability in Bohai Sea area based on AHP-GDM model. Acta Oceanologica Sinica. 2013. 32(4): 41-48 
$\mathrm{Xu} \mathrm{J}$ Y and Zhang L Y. Genesis of Cenozoic basins in the eastern margin of Eurasia Plate: dextral pulling apart. Oil \& Gas Geology. 1999. 20(3): 187-191 (in Chinese)

Yang F T, Pang Z H, Lin L, et al. Hydrogeochemical and isotopic evidence for transformational flow in a sedimentary basin: Implications for $\mathrm{CO}_{2}$ storage. Applied Geochemistry. 2013. 30: 4-15

Yu Y X, Zhou X H, Tang L J, et al. Salt structure in the Laizhouwan Depression, offshore Bohai Bay Basin, East China: New insights from 3D seismic data. Marine and Petroleum Geology. 2009. 26(8): 16001607

Yu Z H, Wu S G, Zou D B, et al. Seismic profiles across the middle Tanlu Fault zone in Laizhou Bay, Bohai Sea, eastern China. Journal of Asian Earth Sciences. 2008. 33(5-6): 383-394

Zhang C M, Liu X F and Ren J Y. Tectonic hydrocarbon accumulation of Laoyemiao region in the Nanpu Sag, Bohai Bay Basin. Acta Geologica Sinica. 2009. 83(5): 951-961

Zhao L and Zheng T Y. Seismic structure of the Bohai Bay Basin, northern China: Implications for basin evolution. Earth and Planetary Science Letters. 2005. 231(1-2): 9-22

Zhou J X and Zhou J S. Mechanisms of Cenozoic deformation in the
Bohai Basin, Northeast China: Physical modelling and discussions. Science in China Series D: Earth Sciences. 2006. 49(3): 258-271

Zhou L H, Fu L X, Lou D, et al. Structural anatomy and dynamics of evolution of the Qikou Sag, Bohai Bay Basin: Implications for the destruction of North China craton. Journal of Asian Earth Sciences. 2012. 47: 94-106

Zhu G, Liu G S, Dunlap W J, et al. ${ }^{40} \mathrm{Ar} /{ }^{39} \mathrm{Ar}$ geochronological constraints on syn-orogenic strike-slip movement of Tan-Lu fault zone. Chinese Science Bulletin. 2004. 49(5): 499-508

Zhu W L, Mi L J and Long Z S. The Hydrocarbon Accumulation and Exploration of Bohai Sea Area. Beijing: Science Press. 2009. 142295 (in Chinese)

Zou C N, Zhu R K, Zhao W Z, et al. Geologic characteristics of volcanic hydrocarbon reservoirs and exploration directions in China. Acta Geologica Sinica. 2010. 84(1): 194-205

Zuo Y H, Qiu N S, Zhang Y, et al. Geothermal regime and hydrocarbon kitchen evolution of the offshore Bohai Bay Basin, North China. AAPG Bulletin. 2011. 95(5): 749-769

(Edited by Hao Jie) 